\title{
REPEATABILITY OF FRUITS AND SEEDS PRODUCTION AND SELECTION OF BRAZIL NUT GENOTYPES IN NATIVE POPULATIONS IN RORAIMA ${ }^{1}$
}

Cássia Ângela Pedrozo ${ }^{2}$, Helio Tonini $^{3}$, Marcos Deon Vilela Resende $^{4}$ e Sônia Maria Schaefer Jordão ${ }^{5}$

\begin{abstract}
This study estimates the repeatability coefficients of two production traits in two native populations of Brazil nut trees. It determines the number of years of suitable evaluations for an efficient selection process, determines the permanent phenotypic correlation between production traits and also the selection of promising trees in these populations. Populations, located in the Itã region (ITA) and in the in the Cujubim region (CUJ), are both belonging to the municipality of Caracaraí, state of Roraima - Brazil, and consist of 85 and 51 adult trees, respectively. Each tree was evaluated regarding the number of fruits per plant (NFP) and fresh seed weight per plant (SWP), for eight (ITA) and five consecutive years (CUJ). Statistical analyses were performed according to the mixed model methodology, using Software Selegen-REML/BLUP (RESENDE, 2007). The repeatability coefficients were low for NFP (0.3145 and 0.3269 for ITA and CUJ, respectively) and also for SWP ( 0.2957 and 0.3436 for ITA and CUJ, respectively). It on average takes nine evaluation years to reach coefficients of determination higher than $80 \%$. Permanent phenotypic correlation values higher than 0.95 were obtained for NFP and SWP in both populations. Although trees with a high number of fruits and seed weight were identified, more evaluation years are needed to perform the selection process more efficiently.
\end{abstract}

Keywords: Bertholletia excelsa; Genetic improvement; Forest resources.

\section{REPETIBILIDADE DE PRODUÇÃO DE FRUTOS E SEMENTES E SELEÇÃO DE GENÓTIPOS DE CASTANHA-DO-BRASIL EM POPULAÇÕES NATIVAS EM RORAIMA}

\begin{abstract}
RESUMO - Os objetivos deste estudo foram estimar coeficientes de repetibilidade de dois caracteres de produção em duas populações nativas de castanheira-do-brasil, determinar o número de anos de avaliações adequado para um eficiente processo de seleção, determinar a correlação fenotípica permanente entre os caracteres de produção e selecionar árvores promissoras nessas populações. As populações, localizadas na região do Itã (ITA) e na região do Cujubim (CUJ), ambas pertencentes ao Município de Caracaraí, Estado de Roraima - Brasil, foram constituídas por 85 e 51 árvores adultas, respectivamente. Cada árvore foi avaliada quanto ao número de frutos por planta (NFP) e peso fresco de sementes por planta (SWP), por oito (ITA) e cinco anos consecutivos (CUJ). As análises estatísticas foram realizadas segundo a metodologia de modelos mistos, utilizando-se o Software Selegen-REML/BLUP (RESENDE, 2007). Os coeficientes de repetibilidade foram baixos tanto para o NFP (0,3145 e 0,3269 para ITA e CUJ, respectivamente) quanto para o SWP (0,2957 e 0,3436 para ITA e CUJ, respectivamente). Em média, são necessários nove anos de avaliação para que sejam alcançados coeficientes de determinação superiores a 80\%. Valores de correlação
\end{abstract}

\footnotetext{
${ }^{1}$ Recebido em 10.12.2013 aceito para publicação em 10.06.2015.

${ }^{2}$ Empresa Brasileira de Pesquisa Agropecuária, Centro de Pesquisa Agloflorestal de Roraima, Boa Vista, RR - Brasil. E-mail: <cassia.pedrozo@embrapa.br>.

${ }^{3}$ Empresa Brasileira de Pesquisa Agropecuária, Embrapa Agrossilvipastoril, Sinop, MT - Brasil. E-mail: $<$ helio.tonini@embrapa.br>.

${ }^{4}$ Empresa Brasileira de Pesquisa Agropecuária, Centro Nacional de Pesquisa de Florestas, Colombo, PR - Brasil. E-mail: $<$ marcos.resende@embrapa.br>.

${ }^{5}$ Empresa Brasileira de Pesquisa Agropecuária, Embrapa Amazônia Oriental, Belém, PA-Brasil. E-mail: <sonia.jordao@embrapa.br>
}

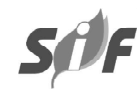

Revista Árvore, Viçosa-MG, v.39, n.5, p.863-871, 2015 http://dx.doi.org/10.1590/0100-67622015000500009 
fenotipica permanente entre NFP e SWP acima de 0,95 foram obtidos nas duas populações. Apesar de ter sido possivel identificar árvores com elevado número de frutos e peso de sementes, número maior de anos de avaliação é necessário para que o processo seletivo seja realizado de forma mais eficiente.

Palavras-chave: Bertholletia excelsa; Melhoramento Genético; Recursos Florestais.

\section{INTRODUCTION}

The Brazil nut tree (Bertholletia excelsa HBK) occurs in about 325 million hectares of Amazon forests from Venezuela, Colombia, Peru, Bolivia, Guyanas and Brazil. However, the highest densities are found in the latter country, in the states of Roraima, Rondônia, Acre, Amapá, Amazonas, Pará, Maranhão and Mato Grosso (LORENZI, 2000; STOIAN, 2004).

The Brazil nut chain has great ecological, social and economic value for the Amazon region, creating jobs and income for thousands of the region's rural and urban workers (CLAY, 1997; TONINI, 2011). Only in Brazil, in 2006, the product moved about R \$ 43.9 million (MDIC/SECEX, 2009).

The nut kernel is known in the market for its high nutritional value, as it is rich in lipids, proteins, fibers, vitamins, and minerals, and especially selenium (CARDARELLI; OLIVEIRA, 2000; GONÇALVES et al., 2002; SOUZA; MENEZES, 2004). This last element has antioxidant activity and is, therefore, recommended in the prevention of cancer and cardiovascular diseases.

The collection of nuts is performed almost exclusively from native trees, which have been under constant threats due to deforestation. These facts, coupled with the high demand of the product in the domestic and international market justify the introduction of Brazil nut tree cultivation, considered a viable reforestation alternative (TONINI et al., 2005). This alternative, however, will only be effective if it is based on planting of high genetic quality materials.

Given that perennial species have a long production cycle, the optimal number of measures (crops) to be evaluated has to be determined for the selection of superior genotypes. This determination can be accomplished through the coefficient of repeatability, which helps to increase the selection efficiency and also reduces the time and hand labor costs in the selection process (CRUZ et al., 2004).

Statistically, the coefficient of repeatability is defined as the correlation between the measurements obtained for the same individual, repeated in time or space, and is equivalent to the maximum value that broad-sense heritability can achieve (FALCONER; MACKAY, 1996). For species with vegetative propagation possibility, such as the Brazil nut tree, the repeatability instead of broad-sense heritability can be considered a suitable parameter to infer on the genetic control of the traits (BROWN et al., 2009).

Obtaining a high repeatability coefficient value for a specific trait indicates that it is possible to predict the actual value of the individual with few measurements, and thus, increasing the number of evaluations will not significantly increase the accuracy to predict the phenotypic value. However, when the coefficient of repeatability is low, a large number of measurements will be needed to attain a significant accuracy increase in the selection (CRUZ et al., 2004).

Repeatability coefficients were estimated in a series of perennial crops of economic importance, as for example cupuaçu trees (Theobroma grandiflorum (Willd. ExSpreng) Schum.), acerola trees (Malpighia emarginata DC.) and açaí trees (Euterpe oleracea Mart.) (COSTA et al., 1997; LOPES et al., 2000; OLIVEIRA et al., 2001). However, there is no available information on this parameter for Brazil nut trees.

Based on the above, the objectives of this study were: 1) to estimate the coefficients of repeatability for the number of fruits per plant and fresh seed weight per plant; 2) to determine the number of suitable evaluation years for an efficient selection process; 3 ) to determine the permanent phenotypic correlation between the production traits and; 4) to select promising trees in two native populations of Brazil nut trees in Roraima.

\section{MATERIALAND METHODS}

The study was conducted on two native populations of Brazil nut trees, located in the municipality of Caracaraí, state of Roraima-Brazil. According to the Köppen classification, the region has a predominant Awi humid tropical climate, with average annual temperature of $28^{\circ} \mathrm{C}$ and average annual rainfall of $1.850 \mathrm{~mm}$. The 
vegetation classification is Open Tropical Forest with large number of palm trees (BRASIL, 1975). Population called ITA is located in the Itã region, with predominantly Yellow and Red-Yellow Argisol. The other population, called CUJ, is located in the Cujubim region, with predominantly Red-Yellow Argisol.

Each population was delimited by a permanent plot of nine hectares $(300 \mathrm{~m} \times 300 \mathrm{~m})$, considering in the study all Brazil nut trees with diameter at breast height $\geq 50 \mathrm{~cm}$, which are considered adults according to Wadt et al. (2005). Thus, the ITA and CUJ populations consisted of 85 and 51 trees, respectively.

The ITA population was evaluated for eight consecutive years (2006 to 2013), and CUJ for five years (2009 to 2013). The trees were evaluated regarding the number of fruits per plant (NFP) and fresh seed weight per plant (SWP), expressed in kg. The NFP was obtained by counting all fallen fruits under the tree canopies, and the SWP by weighting the seeds removed from the fruits using a $50 \mathrm{~g}$ accuracy digital hook scale.

Statistical analyses were performed according to the mixed-model methodology, where the variance components per population were estimated by the restricted maximum likelihood (REML) method, and the phenotypic values of the individuals were predicted by the best linear unbiased prediction (BLUP).

The following statistical model was used for the analyses (RESENDE, 2002):

$$
y=X m+W p+e, \text { where: }
$$

$y$ is the data vector; $m$ is the vector of effects of the assessment years (assumed to be fixed) added to the overall average; $p$ is the vector of permanent effects of plants (genotypic effects + permanent environmental effects) (assumed to be random); and $e$ is the vector of errors or residues (random). Capital letters represent the matrices of incidence for the effects of $m$ and $p$, respectively.

The following components of phenotypic variance and parameters are provided by:

$\mathrm{V}_{\mathrm{fp}}$ : permanent phenotypic variance between plants (genotype + permanent environment from one assessment year to another);

$\mathrm{V}_{\mathrm{et}}$ : temporary environment variance;

$\mathrm{V}_{\mathrm{f}}$ : individual phenotypic variance;

r: individual repeatability; $r_{m}$ : repeatability of the average of $m$ evaluation years;

$A_{c m}$ : accuracy of selection based on the average of $\mathrm{m}$ evaluation years;

$\mathrm{E}_{\mathrm{f}}$ : efficiency of the number of evaluation years compared to performing only one year of evaluation.

$\mathrm{m}$ : overall average.

The permanent phenotypic values obtained were used to determine the permanent phenotypic correlation between NFP and SWP and the index adapted from Mulamba and Mock (1978) including both traits. Superior trees were selected according to the permanent phenotypic values for each trait individually and by the average ranks.

All previously reported analyses were performed using the Selegen-REML/BLUP software (RESENDE, 2007).

\section{RESULTS}

Table 1 shows the variance components and phenotypic parameter estimates for number of fruits per plant (NFP) and fresh seed weight per plant (SWP), evaluated in two Brazil nut native populations in Roraima. The mean values of the two traits were 111.13 fruits/ plant and $13.76 \mathrm{~kg}$ of seed/plant in CUJ and 22.18 fruits/ plant and $3.55 \mathrm{~kg}$ of seed/plant in the ITA population. Independent of the population, NFP and SWP traits exhibited a higher temporary environment variance estimate $\left(\mathrm{V}_{\mathrm{et}}\right)$ than the estimate of permanent phenotypic variance between plants $\left(\mathrm{V}_{\mathrm{fp}}\right)$.

In the ITA population, the coefficients of individual repeatability (r) were 0.3269 and 0.3436 , for the NFP and SWP traits, respectively. In the CUJ population, the values were 0.3145 and 0.2957 , respectively. Despite the low $r$ estimates obtained in the present study, the accuracy estimates $\left(\mathrm{A}_{\mathrm{cm}}\right)$ associated with this parameter were high (greater than $82.0 \%$ ) in all trait $\mathrm{x}$ population combinations evaluated, leading to the $\mathrm{r}_{\mathrm{m}}$ of approximately 0.80 and 0.70 for ITA e CUJ, respectively.

The estimates of the determination coefficients $\left(\mathrm{C}_{2}\right)$, of the accuracy of the permanent phenotypic values based on $m$ years of evaluation $\left(\mathrm{A}_{\mathrm{cm}}\right)$ and of the selective efficiency of $m$ measurements, compared to when only one evaluation is performed (Ef), are presented at Table 2 . For the NFP trait, independent of the population, it will require nine years of evaluation in order to achieve

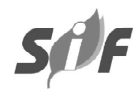

Revista Árvore, Viçosa-MG, v.39, n.5, p.863-871, 2015 
Table 1 - Variance components and phenotypic parameter estimates for number of fruits per plant (NFP) and fresh seed weight per plant (SWP), in two native populations of Brazil nut (ITA e CUJ) in Roraima. Caracaraí-RR, 2013.

Tabela 1 - Componentes de variância e estimativas dos parâmetros fenotípicos dos caracteres número de frutos por planta (NFP) e peso fresco de sementes por planta (SWP), em duas populações nativas de castanheira-do-brasil (ITA e CUJ) em Roraima. Caracarai -RR, 2013.

\begin{tabular}{|c|c|c|c|}
\hline \multirow{2}{*}{ Population } & \multicolumn{3}{|c|}{ Trait } \\
\hline & & NFP & SWP \\
\hline \multirow{7}{*}{ ITA } & $\mathrm{V}_{\text {ff }}$ & 655.6919 & 17.8572 \\
\hline & $V_{e t}^{p t}$ & 1349.9390 & 34.1158 \\
\hline & $V_{f}^{e t}$ & 2005.6310 & 51.973 \\
\hline & $\mathrm{r}$ & $0.3269 \pm 0.0620^{1}$ & $0.3436 \pm 0.0636$ \\
\hline & $\mathrm{r}_{\mathrm{m}}$ & 0.7953 & 0.8072 \\
\hline & $\mathrm{A}_{\mathrm{cm}}^{\mathrm{m}}$ & 0.8918 & 0.8985 \\
\hline & $\mathrm{m}$ & 22.1841 & 3.5471 \\
\hline \multirow{7}{*}{ CUJ } & $\mathrm{V}_{\mathrm{fp}}$ & 7910.931 & 120.0863 \\
\hline & $\mathrm{V}_{\mathrm{et}}^{\mathrm{p}}$ & 17240.3200 & 286.0771 \\
\hline & $\mathrm{V}_{\mathrm{f}}^{\mathrm{a}}$ & 25151.2500 & 406.1635 \\
\hline & $\mathrm{r}$ & $0.3145 \pm 0.0993$ & $0.2957 \pm 0.0963$ \\
\hline & $\mathrm{r}_{\mathrm{m}}$ & 0.6964 & 0.6773 \\
\hline & $\mathrm{A}_{\mathrm{cm}}$ & 0.8345 & 0.823 \\
\hline & $\mathrm{m}$ & 111.1322 & 13.7556 \\
\hline
\end{tabular}

${ }^{1}$ Standard deviation of the estimate; Vfp: permanent phenotypic variance between plants; Vet: temporary environment variance; Vf: individual phenotypic variance; r: individual repeatability; rm: repeatability of the average of m evaluation years; Acm: accuracy of selection based on the average of $\mathrm{m}$ evaluation years; and $\mathrm{m}$ : overall average.

determination coefficients greater than $80 \%$. Regarding the SWP, it will require eight years of evaluation in the ITA and ten in the CUJ population. The values associated with $\mathrm{A}_{\mathrm{cm}}$ and $\mathrm{Ef}$, regarding the evaluation years, were high for both traits (approximately $90 \%$ and 1.6 , respectively).

Table 3 shows the permanent phenotypic values $\left(\mu+f_{p}\right)$, the gains and new averages after selection for ten superior trees in each population, for the two traits evaluated individually, and also the average ranking of the trees selected based on the index adapted from Mulamba and Mock (1978). With the exception of the ITA-10 tree and CUJ-02 and CUJ-04 trees, all other trees selected for NFP were also selected for SWP. The selection made on the basis of average rankings also showed high coincidence with the selection where each trait was considered separately. High permanent phenotypic correlation values were obtained between NFP and SWP in the two populations ( 0.9786 and 0.9582 in the ITA and CUJ populations, respectively; data not presented).

The average phenotypic value of the trees selected for NFP and SWP were higher than the overall average phenotypic value obtained for these traits. The trees
ITA-28 and ITA-49 showed NFP values that were 4.04 and 5.53 greater than the overall average for this trait, respectively, while for SWP, the values were 4.99 and 5.24 greater, respectively. For the trees CUJ-12 and CUJ-40, the NFP values were 3.31 and 3.19 times greater than the overall average, while for SWP the values were 3.24 and 3.23 , respectively.

\section{DISCUSSION}

The average yield of Brazil nut seeds obtained in the ITA population was lower than that obtained in a study conducted at the Chico Mendes Extractive Reserve (RESEX) in Acre (WADT et al., 2005) and similar to that obtained at São João da Baliza in Roraima (TONINI et al., 2008). These authors obtained 10.28 and $4.07 \mathrm{~kg}$ of seed/plant, respectively. However, the average yield in the CUJ population was higher than that values obtained at RESEX and at São João da Baliza. The differences between populations might be due to genetic and also due to environmental conditions.

The higher value of $\mathrm{V}_{\mathrm{e}}$ as compared to that of $\mathrm{V}_{\mathrm{fp}}$ indicates that the NFP and SWP traits are highly influenced by environmental conditions, which 
Table 2 - Determination coefficient $\left(\mathrm{C}_{2}\right)$, accuracy of the permanent phenotypic values based on $m$ years of evaluation $\left(A_{c m}\right)$ and efficiency of m measurements compared to when only one evaluation is performed (Ef), for the number of fruits per plant (NFP) and fresh seed weight per plant (SWP) evaluated in two Brazil nut native populations (ITA and CUJ) in Roraima. Caracaraí - RR, 2013.

Tabela 2 - Coeficiente de determinação $\left(C_{2}\right)$, acurácia dos valores fenotípicos permanentes baseados em $m$ anos de avaliação $\left(A_{c m}\right)$ e eficiência das $m$ avaliações, comparadas com a situação em que apenas uma avaliação é realizada (Ef), quanto aos caracteres número de frutos por planta (NFP) e peso de sementes por planta (SWP), avaliadas em duas populações nativas de castanheira-do-brasil (ITA e CUJ) em Roraima. Caracaraí - RR, 2013.

\begin{tabular}{|c|c|c|c|c|c|c|c|}
\hline & \multirow[b]{2}{*}{$\mathrm{m}$} & \multicolumn{3}{|c|}{ NFP } & \multicolumn{3}{|c|}{ SWP } \\
\hline & & $\mathrm{C}_{2}$ & $\mathrm{~A}_{\mathrm{cm}}$ & Ef & $\mathrm{C}_{2}$ & $\mathrm{~A}_{\mathrm{cm}}$ & Ef \\
\hline \multirow{9}{*}{ ITA } & 1 & 0.3269 & 0.5718 & 1.0000 & 0.3436 & 0.5862 & 1.0000 \\
\hline & 2 & 0.4928 & 0.7020 & 1.2277 & 0.5114 & 0.7152 & 1.2201 \\
\hline & 3 & 0.5930 & 0.7701 & 1.3468 & 0.6109 & 0.7816 & 1.3335 \\
\hline & 4 & 0.6602 & 0.8125 & 1.4211 & 0.6768 & 0.8227 & 1.4035 \\
\hline & 5 & 0.7083 & 0.8416 & 1.4720 & 0.7235 & 0.8506 & 1.4512 \\
\hline & 6 & 0.7445 & 0.8629 & 1.5091 & 0.7585 & 0.8709 & 1.4858 \\
\hline & 7 & 0.7727 & 0.8791 & 1.5374 & 0.7856 & 0.8863 & 1.5121 \\
\hline & 8 & 0.7953 & 0.8918 & 1.5597 & 0.8072 & 0.8985 & 1.5328 \\
\hline & 9 & 0.8138 & 0.9021 & 1.5778 & 0.8249 & 0.9082 & 1.5495 \\
\hline \multirow{11}{*}{ CUJ } & 10 & 0.8293 & 0.9106 & 1.5927 & 0.8396 & 0.9163 & 1.5632 \\
\hline & 1 & 0.3145 & 0.5608 & 1.0000 & 0.2957 & 0.5437 & 1.0000 \\
\hline & 2 & 0.4785 & 0.6918 & 1.2335 & 0.4564 & 0.6756 & 1.2424 \\
\hline & 3 & 0.5792 & 0.7611 & 1.3570 & 0.5574 & 0.7466 & 1.3730 \\
\hline & 4 & 0.6473 & 0.8046 & 1.4346 & 0.6267 & 0.7917 & 1.4559 \\
\hline & 5 & 0.6964 & 0.8345 & 1.4880 & 0.6773 & 0.8230 & 1.5135 \\
\hline & 6 & 0.7336 & 0.8565 & 1.5272 & 0.7158 & 0.8460 & 1.5560 \\
\hline & 7 & 0.7626 & 0.8733 & 1.5571 & 0.7461 & 0.8638 & 1.5885 \\
\hline & 8 & 0.7859 & 0.8865 & 1.5807 & 0.7705 & 0.8778 & 1.6144 \\
\hline & 9 & 0.8051 & 0.8973 & 1.5999 & 0.7907 & 0.8892 & 1.6353 \\
\hline & 10 & 0.8211 & 0.9061 & 1.6157 & 0.8076 & 0.8987 & 1.6527 \\
\hline
\end{tabular}

hinders the selection of promising genotypes based on simple genetic improvement methods, meaning those that take into account only the phenotype of the individual.

Environmental variation may has been pronounced, among other factors, by the effect of pollinating insects on the fertilization rate of the flowers and by the occurrence of incompatibility between genotypes, factors arising from the predominance of crossfecundation, proven for the species (O'MALLEY et al., 1988). Similar results were also reported by Oliveira and Moura (2010), by estimating the repeatability coefficients of bacabi clusters (Oenocarpus mapora).

Given the occurrence of high environmental variation, it is recommended the use of suitable experimental designs, genetic improvement methods that have good parental control or the application of indirect selection, by studying correlations between traits of interest and traits that have better genetic control (COSTA, 2003).

The low magnitudes of individual repeatability show the lack of regularity in the repetition of the two traits in the following evaluation years, consequently causing difficulties in the selection process of superior genotypes based on few evaluation years. Low repeatability coefficients were observed for the production traits in several other perennial species, such as the peach-palm (Bactris gasipaes Kunth), the Brazilian shrub (Paullinia cupana) and the açaí palm (Euterpe oleracea Mart.) (OLIVEIRA; FERNANDES, 2001; PADILHA et al., 2003; NASCIMENTO FILHO et al., 2009).

High values of $A_{c m}$, which ensure reliability in the evaluation and selection of the individuals, may be result from high repeatability estimates of the average of $\mathrm{m}$ evaluation years $\left(\mathrm{r}_{\mathrm{m}}\right)$ associated with 
Table 3 - Permanent phenotypic values $\left(\mu+f_{p}\right)$, gains, new averages after selection and average ranks of ten superior trees in two native populations of Brazil nut (ITA and CUJ), evaluated for the number of fruits per plant (NFP) and fresh seed weight per plant (SWP). Caracaraí - RR, 2013.

Tabela 3 - Valores fenotípicos permanentes $\left(\mu+f_{p}\right)$, ganhos, novas médias após a seleção e ranks médios de 10 árvores superiores em duas populações nativas de castanheira-do-brasil (ITA e CUJ), avaliadas quanto aos caracteres número de frutos por planta (NFP) e peso de sementes por planta (SWP). Caracarai - RR, 2013.

\begin{tabular}{|c|c|c|c|c|c|c|c|c|c|c|}
\hline \multicolumn{11}{|c|}{ ITA } \\
\hline \multirow[b]{2}{*}{ Rank } & \multicolumn{4}{|c|}{ NFP } & \multicolumn{4}{|c|}{ SWP $(\mathrm{kg})$} & \multirow[b]{2}{*}{ Tree } & \multirow[b]{2}{*}{ Average rank } \\
\hline & Tree & $\mu+f_{p}$ & Gain & New average & Tree & $\mu+f_{p}$ & Gain & New average & & \\
\hline 1 & ITA-49 & 122.65 & 100.46 & 122.65 & ITA-28 & 18.5759 & 15.0288 & 18.5759 & ITA-49 & 1.50 \\
\hline 2 & ITA-51 & 89.94 & 84.11 & 106.29 & ITA-49 & 17.7142 & 14.5979 & 18.1450 & ITA-28 & 2.00 \\
\hline 3 & ITA-28 & 89.54 & 78.52 & 100.71 & ITA-5 1 & 15.8111 & 13.8200 & 17.3671 & ITA-51 & 2.50 \\
\hline 4 & ITA-61 & 71.84 & 71.31 & 93.49 & ITA-04 & 11.8749 & 12.4470 & 15.9940 & ITA-04 & 4.50 \\
\hline 5 & ITA-04 & 65.68 & 65.75 & 87.93 & ITA-26 & 11.1454 & 11.4772 & 15.0243 & ITA-61 & 5.00 \\
\hline 6 & ITA-10 & 64.69 & 61.87 & 84.06 & ITA-61 & 9.8276 & 10.6111 & 14.1582 & ITA-26 & 6.50 \\
\hline 7 & ITA-17 & 59.72 & 58.39 & 80.58 & ITA-92 & 9.0678 & 9.8839 & 13.4310 & ITA-17 & 7.50 \\
\hline 8 & ITA-26 & 57.33 & 55.49 & 77.67 & ITA-17 & 8.8357 & 9.3095 & 12.8566 & ITA-92 & 8.00 \\
\hline 9 & ITA-92 & 54.65 & 52.93 & 75.11 & ITA-91 & 8.2475 & 8.7974 & 12.3445 & ITA-10 & 9.00 \\
\hline 10 & ITA-91 & 53.45 & 50.76 & 72.95 & ITA-47 & 8.1334 & 8.3763 & 11.9234 & ITA-91 & 9.50 \\
\hline $\mathrm{mg}$ & & 22.18 & & & & 3.5471 & & & & \\
\hline $\mathrm{ms}$ & & 72.95 & & & & 11.9234 & & & & \\
\hline Rank & Tree & $\mu+f_{p}$ & Gain & New average & Tree & $\mu+f_{p}$ & Gain & New average & Tree & Average rank \\
\hline 1 & CUJ-12 & 367.75 & 256.62 & 367.75 & CUJ-12 & 44.5238 & 30.7682 & 44.5238 & CUJ-12 & 1.0 \\
\hline 2 & CUJ-40 & 354.79 & 250.14 & 361.27 & CUJ-40 & 44.4358 & 30.7242 & 44.4798 & CUJ-40 & 2.0 \\
\hline 3 & CUJ-54 & 237.23 & 208.79 & 319.93 & CUJ-28 & 26.2411 & 24.6446 & 38.4002 & CUJ-28 & 4.5 \\
\hline 4 & CUJ-42 & 218.43 & 183.42 & 294.55 & CUJ-32 & 26.1611 & 21.5848 & 35.3404 & CUJ-32 & 4.5 \\
\hline 5 & CUJ-32 & 205.81 & 165.67 & 276.80 & CUJ-42 & 25.5489 & 19.6265 & 33.3821 & CUJ-42 & 4.5 \\
\hline 6 & CUJ-28 & 197.40 & 152.44 & 263.57 & CUJ-51 & 25.2021 & 18.2631 & 32.0188 & CUJ-54 & 6.5 \\
\hline 7 & CUJ-19 & 189.18 & 141.81 & 252.94 & CUJ-52 & 24.2214 & 17.1492 & 30.9049 & CUJ-03 & 8.0 \\
\hline 8 & CUJ-03 & 187.79 & 133.67 & 244.80 & CUJ-03 & 23.1973 & 16.1858 & 29.9414 & CUJ-19 & 8.0 \\
\hline 9 & CUJ-02 & 168.01 & 125.13 & 236.27 & CUJ-19 & 20.3703 & 15.1223 & 28.8780 & CUJ-52 & 9.0 \\
\hline 10 & CUJ-04 & 157.70 & 117.28 & 228.41 & CUJ-54 & 20.2308 & 14.2576 & 28.0133 & CUJ-02 & 10.5 \\
\hline $\mathrm{mg}$ & & 111.13 & & & & 13.7556 & & & & \\
\hline $\mathrm{ms}$ & & 228.41 & & & & 28.0133 & & & & \\
\hline
\end{tabular}

$\mathrm{mg}$ : overall average phenotypic values; ms: average phenotypic values of selected plants.

the number of evaluation years actually performed (eight and five years in the ITA and MMV populations, respectively).

According to Falconer (1987) and Cruz et al. (2004), when the coefficient of repeatability shows low magnitude, increasing the evaluations over the years, it can result in a significant increase of accuracy for the selection of superior genotypes. However, once increasing the number of evaluations increases costs and time selection, an attainable number should be carried out. Despite the number of years of evaluation necessary to efficiently select Brazil nut trees is relatively high (in average nine), it is not impractical. This result indicates that nine consecutive evaluation years for
NFP and SWP represent true repetitions and it could be used to select trees of native populations, where is not possible to use experimental designs.

The heritability of yield traits in Brazil nut is unknown. Thus, repeatability coefficients are important for breeding programs, once this coefficient is equivalent to the maximum value that broad-sense heritability can achieve (FALCONER; MACKAY, 1996). According to the results of repeatability, the heritability for SWP and NFP tend to be low (lower than 0.34 and 0.33 , respectively).

There is a relationship between NFP and SWP, showed by the high permanent phenotypic correlation values between these traits, and proved by the high 
coincidence of selected trees for NFP e SWP when each trait was considered separately. Although it is easier to measure NFP than SWP trait, since to evaluate that second trait is necessary to open the fruit for weighing the seeds, the indirect selection for SWP should be viewed with caution, since the relationship of NFP with other important traits for genetic improvement, such as the hardness of the fruit, seed size and seed number per fruit, still needs to be studied.

Camargo et al. (2010), evaluating Brazil nut trees, obtained expressive genetic gain results in the selection for fruit weigh, seed weight per fruit and number of seeds per fruit. The values of NFP e SWP of the tree selected in the present study were also promising. ITA28, ITA-49, CUJ-12 and CUJ-40, among others promising trees, can be used for clone and/or progeny testing and later thinning can be performed to obtain a genetically improved seed orchard. However, the populations need to be evaluated for at least one year, in the case of the ITA population, and four years for CUJ, in order to reach the nine evaluation years estimated to efficiently perform the selection.

\section{CONCLUSION}

The Brazil-nut production traits were highly influenced by environmental conditions and had low coefficients of repeatability. In general, the native populations evaluated will require at least nine consecutive evaluation years for number of fruits per plant and seed weight per plant in order to achieve accuracy greater than $80 \%$ in predicting the value of the individuals. Although the trees selected were very promising, with a high number of fruits and seed weight, more years of evaluation are needed to make the selection process more efficient. Notwithstanding the high permanent phenotypic correlation between NFP and SWP, the possible indirect selection for SWP needs to be further studied.

\section{ACKNOWLEDGMENT}

We would like to thank the field technicians José de Anchieta Moreira da Costa, Adebaldo Sampaio Teles and Taiguara dos Santos Pereira for their assistance in the collection, and also the Company FIT Manejo Florestal Ltda., and José Lopes Primo, who kindly offered his farm areas for the evaluation processes.

\section{REFERENCES}

BRASIL. Ministério de Desenvolvimento, Indústria e Comércio Exterior. Sistema Alice - web. Available in: http://www.mdic.gov.br. Access in: 15 Sept. of 2010.

BRASIL. Departamento Nacional da Produção Mineral. Projeto RADAMBRASIL. Rio de Janeiro: 1975.

BROWN, J.S.; SCHNELL, R.J.; AYALA-SILVA, T.; MOORE, J.M.; TONDO, C.L.; WINTERSTEIN, M.C. Broad-sense heritability estimates for the fruit color and morphological traits from openpollinated half-sib mango families. Hortscience, v.44, p.1552-1556, 2009.

CAMARGO, F.F.; COSTA, R.B.; RESENDE, M.D.V.; ROA, R.A.R.; RODRIGUES, N.B.; SANTOS, L.V.; FREITAS, A.C.A. Variabilidade genética para caracteres morfométricos de matrizes de castanha-do-brasil da Amazônia Matogrossense. Acta Amazônica, v.40, n.4, p.705710,2010 .

CARDARELLI, H.R.; OLIVEIRA, A.J. Conservação do leite de castanha-do-pará. Ciência e Tecnologia de Alimentos, v.57, n.4, p.617, 2000 .

CLAY, J.W., Brazil nuts: the use of a keystone species for conservation and development. In: FREESE, C.H. (Ed.). Harvesting wild species implications for biodiversity conservation. Baltimore: Johns Hopkins University Press: 1997. p.246-282.

COSTA, J.G.; LEDO, A.S.; OLIVEIRA, M.N. Estimativas de repetibilidade de características de frutos de cupuaçuzeiro no Estado do

Acre. Revista Brasileira de

Fruticultura, v.19, n.3, p.313-318, 1997.

COSTA, J.G. Estimativas de repetibilidade de alguns caracteres de produção em mangueira. Ciência Rural, v.33, n.2, p.263-266, 2003.

CRUZ, C.D.; REGAZZI, A.J.; CARNEIRO, P.C.S. Modelos biométricos aplicados ao melhoramento genético. $3^{\mathrm{a}}$.ed. Viçosa, MG: Universidade Federal de Viçosa, 2004. v.1.

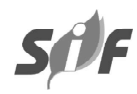

Revista Árvore, Viçosa-MG, v.39, n.5, p.863-871, 2015 
FALCONER, D.S. Introdução à genética quantitativa. Viçosa, MG: Universidade Federal de Viçosa, 1987.

FALCONER, D.S.; MACKAY, T.F.C. Introduction to quantitative genetics. Essex: Longman, 1996.

GONÇALVES, J.F.C.; FERNANDES, A.V.; OLIVEIRA, A.F.M.; RODRIGUES, L.F.; MARENCO, R.A. Primary metabolism components of seeds from Brazilian Amazon tree species. Brazilian Journal Plant Physiology, v.14, n.2, p.139-142, 2002.

LOPES, R.; BRUCKNER, C.H.; CRUZ, C.D.; LOPES, M.T.G.; FREITAS, G.B. Repetibilidade de características do fruto de aceroleira. Pesquisa Agropecuária Brasileira, v.36, n.3, p.507$513,2001$.

LORENZI, H. Árvores brasileiras: manual de identificação de plantas arbóreas nativas do Brasil. 4rd ed. São Paulo: Instituto Plantarum, 2000. v.1.

MULAMBA, N.N.; MOCK, J.J. Improvement of yield potential of the Eto Blanco maize (Zea mays L.) population by breeding for plant traits. Egypt Journal of Genetics and Cytology, v.7, n.1, p.40-51, 1978.

BRASIL. Ministério do Desenvolvimento, Indústria e Comércio Exterior. Secretaria de Comércio Exterior - MDIC/SECEX. Sistema de análise das informações de comércio exterior (ALICE). Disponível em: http:// aliceweb.desenvolvimento. gov.br. Acessado em: ago. 2009.

NASCIMENTO FILHO, F.J.; ATROCH, A.L.; CRUZ, C.D.; CARNEIRO, P.C.S. Repetibilidade da produção de sementes em clones de guaraná. Pesquisa Agropecuária Brasileira, v.44, n.6, p.605-612, 2009.

OLIVEIRA, M.S.P.; FERNANDES, G.L.C. Repetibilidade de caracteres do cacho de açaizeiro nas condições de Belém - PA. Revista Brasileira de Fruticultura, v.23, n.3, p.613-616, 2001.

Revista Árvore, Viçosa-MG, v.39, n.5, p.863-871, 2015
OLIVEIRA, M.S.; MOURA, E.F. Repetibilidade e número mínimo de medições para caracteres de cachos de bacabi (Oenocarpus mapora).

Revista Brasileira de Fruticultura, v.32, n.4, p.1173-1179, 2010.

O’MALLEY, D.M.; BUCKLEY, D.P.; PRANCE, G.T.; BAWA, K.S. Genetic of Brasil nut (Bertholletia excelsa Humb. \& Bonpl., Lecythidaceae). 2. Mating system. Theoretical and Applied Genetics, v.76, n.1, p.929-932, 1988.

PADILHA, N.C.C.; OLIVEIRA, M.S.P.; MOTA, M.G.C. Estimativa da repetibilidade em caracteres morfológicos e de produção de palmito em pupunheira (Bactris gasipaes Kunth). Revista Árvore, v.27, n.4, p.435-442, 2003.

\section{RESENDE, M.D.V. Genética biométrica e} estatística no melhoramento de plantas perenes. Brasília: Embrapa Informação Tecnológica, 2002.

RESENDE, M.D.V. SELEGEN-REML/ BLUP - Sistema Estatístico e Seleção Genética Computadorizada via Modelos Lineares Mistos. Colombo: Embrapa Florestas, 2007.

STOIAN, D. Cosechando lo que cae: la economía de la castaña Bertholletia excelsa H.B.K em la amazônia boliviana. In: ALEXIADES, M.N.; SHANLEY, P. (Ed.). Productos forestales, medios de subsistencia y conservación de productos forestales no maderables. Borgor: Cifor, 2004. p.89-116.

SOUZA, M.L.; MENEZES, H.C. Processamento de amêndoa e torta de castanha-do-Brasil e farinha de mandioca: parâmetros de qualidade. Ciência e Tecnologia de Alimentos, v.24, n.1, p.120-128, 2004.

TONINI, H.; ARCO-VERDE, M.F.; SÁ, S.P.P. Dendrometria de espécies nativas em plantios homogêneos no Estado de Roraima - Andiroba (Carampa guianensis Aubl), castanha-do-Brasil (Bertholletia excelsa Bonpl.), ipê-roxo (Tabebuia avellanedae Lorentz ex Griseb) e jatobá (Hymenaea courbaril L.). Acta Amazônica, v.35, p.353-362, 2005. 
TONINI, H.; COSTA, P.; KAMINSKI, P.E.

Estrutura e produção de duas populações nativas de Castanheira-do-Brasil (Berthollettia excelsa O. Berg) em Roraima. Floresta, v.38, n. 3, 2008 .

TONINI, H. Fenologia da castanheira-do-brasil (Bertholletia excelsa Humb. \& Bonpl.,
Lecythidaceae) no sul do estado de Roraima. Cerne, v.17, n.1, p.123-131, 2011.

WADT, L.H.O.; KAINER, K.A.; GOMES-SILVA, D.A.P. Population structure and nut yield of a Bertholletia excelsa stand in Southwestern Amazonia. Forest Ecology and Management, v.211, p.371-384, 2005. 